\title{
Comparison of the in vitro pathogenicity of two Salmonella Typhimurium phage types
}

\author{
An T.T. Vo ${ }^{\mathrm{a}, \mathrm{d}}$, Engeline van Duijkeren ${ }^{\mathrm{a}}$, Ad C. Fluit ${ }^{\mathrm{b}}$, Henno \\ G.C.J.M. Hendriks ${ }^{\mathrm{c}}$, Peter C.J. Tooten ${ }^{\mathrm{c}}$, Wim Gaastra ${ }^{\mathrm{a}, *}$ \\ ${ }^{a}$ Department of Infectious Diseases and Immunology, Faculty of Veterinary Medicine, Utrecht University, \\ P.O. Box 80165, 3508 TD Utrecht, The Netherlands \\ ${ }^{\mathrm{b}}$ Eijkman-Winkler Institute, University Medical Centre Utrecht, Utrecht University, 3508 GA Utrecht, \\ The Netherlands \\ ${ }^{\mathrm{c}}$ Department of Pathobiology, Faculty of Veterinary Medicine, Utrecht University, 3508 TD Utrecht, \\ The Netherlands \\ ${ }^{\mathrm{d}}$ Faculty of Animal Science and Veterinary Medicine, NongLam University, Thu Duc, \\ Ho Chi Minh City, Vietnam
}

Accepted 15 September 2006

\begin{abstract}
The in vitro pathogenicity of Salmonella enterica serovar Typhimurium phage type (pt) 90 and pt 506 (also known as DT 104) isolates from human and porcine origin was studied in adhesion and invasion assays to the human cell line Caco-2 and the porcine cell line IPI-2. Interleukin-8 (IL-8) production by these two cell lines in response to stimulation by the two Salmonella phage types was also measured. Generally, Salmonella Typhimurium pt 506 and pt 90 adhered to and invaded Caco-2 cells and IPI- 2 cells equally well. The release of IL- 8 by Caco-2 cells or by IPI-2 cells was similar, independent of the Salmonella phage type used for stimulation of the cells. These data suggest that Salmonella Typhimurium pt 90 has a similar ability to cause Salmonella infections as Salmonella Typhimurium DT 104.
\end{abstract}

(C) 2006 Elsevier Ltd. All rights reserved.

Keywords: Salmonella Typhimurium; Phage type; Adhesion; Invasion; IL-8; Epithelial cell

\footnotetext{
${ }^{*}$ Corresponding author. Tel.: + 3130253 1467; fax: + 31302540784 .

E-mail address: w.gaastra@vet.uu.nl (W. Gaastra).
} 


\section{Résumé}

Le pouvoir pathogène d'isolats de Salmonella enterica sérotype Typhimurium phage-type (pt) 90 et pt 506 (connu aussi comme DT104) d'origine humaine et porcine a été étudié in vitro par des tests d'invasion et d'adhérence sur la lignée cellulaire humaine Caco-2 et sur la lignée cellulaire porcine IPI-2. La production d'interleukine 8 (IL-8) par ces lignées cellulaires en réponse à la stimulation par les deux phages-types de Salmonella a été mesurée. En général, Salmonella Typhimurium pt 506 et pt 90 adhèrent aux cellules Caco-2 et IPI-2 et les envahissent de la même manière. La production d'IL-8 par les cellules Caco-2 ou par les cellules IPI-2 était comparable indépendamment du phage-type utilisé pour la stimulation des cellules. Ces données suggèrent que $S$. Typhimurium pt90 ait une capacité semblable à $S$. Typhimurium DT 104 à causer des infections.

(C) 2006 Elsevier Ltd. All rights reserved.

Mots Clés: Salmonella Typhimurium; Phage-type; Adhérence; Invasion; IL-8; Cellule épithéliale

\section{Introduction}

Salmonella Typhimurium is one of the most common causes of salmonellosis worldwide [1]. The prevalence of the predominant phage types of Salmonella Typhimurium differs between different regions [2-5]. Salmonella Typhimurim phage type (Definitive Type or DT) 104, which corresponds to Salmonella Typhimurium phage type (pt) 506 in the Dutch phage typing system [2], is the predominant Salmonella Typhimurium phage type in many European countries and the USA [3]. In Vietnam, however, Salmonella Typhimurium Dutch pt 90 (which has no recognized phage type in the English typing system), is the most prevalent phage type of Salmonella Typhimurium [6].

Despite their close genetic relationship, differences in epidemiology and virulence of different Salmonella serovars and phage types are common. Salmonella lipopolysacharides (LPS), a surface structure, serves as the attachment site for bacteriophages $[7,8]$. The sensitivity and ability of the bacteriophages to distinguish different closely related Salmonella strains is the basis for phage typing systems $[9,10]$. The surface structures are also often virulence factors and as such targets of the innate and adaptive host defense.

Upon infection by Salmonellae, enterocytes do not act as passive victims of infection but signal infection to the immune system. The recognition of the Salmonella flagellin protein by Toll-like receptor 5 (TLR-5) of host cells leads to the release of inflammatory mediators like cytokines and chemokines (such as IL-8) from different types of host cells [11]. IL-8 secretion leads to the attraction and activation of polymorphonuclear leukocytes causing acute inflammation [12].

In vitro studies can reveal important principles of pathogenesis [13]. Adhesion and invasion in host cells can be regarded as exponents of the pathogenesis of Salmonella Typhimurium [14]. In the present study, adhesion and invasion experiments using two intestinal epithelial cell lines were performed in order to compare the pathogenicity of Salmonella Typhimurium pt 506 and Salmonella Typhimurium pt 
90 from human and porcine origin. In addition, the IL- 8 production by these two cell lines in response to stimulation by isolates of the two Salmonella Typhimurium phage types were measured since the magnitude of the cytokine response, for which IL-8 is used as a marker, reflects the intensity of the host-pathogen interaction.

\section{Materials and methods}

\subsection{Bacteria}

The Salmonella Typhimurium isolates were from two collections of non-typhoid Salmonellae cultured from humans and animals in The Netherlands and in Vietnam as described in previous studies [6,15]. Serotyping and phage typing was performed to classify the isolates. Four Salmonella Typhimurium pt 506 isolates from humans (N176, N216) and pigs (N94, N235) in The Netherlands and four Salmonella Typhimurium pt 90 isolates from humans (V15, V22) and pigs (V226, V291) in Vietnam were randomly chosen from the mentioned collections and included in this study (Table 1). A wild-type Salmonella Enteritidis 706 strain was used as a positive control in all assays using the procedure described elsewhere [16]. For the adhesion and invasion experiments, an overnight culture of bacteria was diluted 1/100 in Luria Bertani (LB) broth, grown for $2 \mathrm{~h}$, collected by centrifugation (1500g for $15 \mathrm{~min}$ ) and resuspended in plain Dulbecco's Modified Eagle Medium (DMEM) (Invitrogen) to a concentration of approximately $10^{8}$ bacteria $/ \mathrm{ml}$.

\subsection{Cell cultures}

The human colon adenocarcinoma cell line (Caco-2, ATCC CRC 11268), that is known to exhibit enterocyte-like differentiation patterns, was used [17]. At late confluency Caco-2 cells display the structural and functional differentiation characteristics of small intestinal enterocytes [18]. Caco-2 cells were cultured in high glucose (4.5 g/1) DMEM supplemented with $1 \%(\mathrm{v} / \mathrm{v})$ non-essential amino acids (Flow Laboratories, The Netherlands), $10 \mathrm{mM} \mathrm{NaHCO}, 25 \mathrm{mM} \mathrm{HEPES,} 4 \mathrm{mM}$ glutamine (Flow Laboratories), and 20\% (v/v) fetal calf serum (Cambrex, Belgium) in a humidified atmosphere of $5 \% \mathrm{CO}_{2}$ at $37^{\circ} \mathrm{C}$.

The swine miniature male ileum cell line (IPI-2, ECACC 93100622) immortalized by transfection with an SV40 plasmid which yields morphologically heterogeneous colonies of typical porcine epithelial cells [19] was also used. IPI-2 cells were cultured in the same medium but supplemented with $10 \%$ fetal calf serum and $0.024 \mathrm{IU} / \mathrm{ml}$ insulin. Cell medium was changed three times a week. Caco-2 cells and IPI-2 cells were seeded in 12-well plates (Greiner) and cultured for 19 days and 5 days at 40,000 and 50,000 cells $/ \mathrm{cm}^{2}$, respectively. IPI-2 cells were used at confluency.

\subsection{Adhesion assay}

The adhesion and invasion assays were performed essentially as described [17,18]. Briefly, epithelium cells were washed twice with plain DMEM and incubated for at 
Table 1

Comparison of the adhesion, invasion capacity of Salmonella Typhimurium isolates of phage type 506 and phage type 90 to Caco-2 and IPI-2 cells and Salmonella induced IL-8 production by Caco-2 and IPI-2 cells

\begin{tabular}{|c|c|c|c|c|c|}
\hline Cell line & Strain ID & Phage type & Adhesion $^{\mathrm{a}}$ & Invasion $^{\mathrm{b}}$ & IL- $8^{\mathrm{c}}$ \\
\hline \multirow[t]{11}{*}{ Caco-2 } & N216 & pt 506 & $25.8 \pm 6.3$ & $13.6 \pm 3.5$ & $425.3 \pm 32.2$ \\
\hline & N176 & pt 506 & $22 \pm 0.6$ & $2.6 \pm 1.4$ & $323.4 \pm 39.1$ \\
\hline & $\mathrm{N} 235$ & pt 506 & $3.6 \pm 0.5$ & $4.5 \pm 0.8$ & $501.0 \pm 39.4$ \\
\hline & N94 & pt 506 & $2.5 \pm 0.4$ & $1 \pm 1.0$ & $375.4 \pm 41.9$ \\
\hline & \multicolumn{2}{|c|}{ Mean for the group of pt 506} & $11.4 \pm 10.9$ & $5.44 \pm 5.3$ & $406.3 \pm 75.8$ \\
\hline & V15 & pt 90 & $21.6 \pm 17.2$ & $3.5 \pm 0.7$ & $329.0 \pm 48.2$ \\
\hline & V22 & pt 90 & $2 \pm 0.3$ & $11.2 \pm 1.0$ & $388.6 \pm 40.3$ \\
\hline & V291 & pt 90 & $2.2 \pm 0.5$ & $8.6 \pm 4.6$ & $376.5 \pm 40.3$ \\
\hline & V226 & pt 90 & $1.7 \pm 0.1$ & $7 \pm 5.4$ & $274.8 \pm 29.8$ \\
\hline & Mean for & of pt 90 & $9 \pm 13.8$ & $7.67 \pm 4.2$ & $345.8 \pm 57.5$ \\
\hline & Salmonella & lis (control) & $1.6 \pm 1.3$ & $3.5 \pm 0.6$ & $654 \pm 98$ \\
\hline \multirow[t]{11}{*}{ IPI-2 } & $\mathrm{N} 216$ & pt 506 & $7 \pm 3.4$ & $1.3 \pm 0.7$ & $391.1 \pm 34.2$ \\
\hline & N176 & pt 506 & $11 \pm 5.1$ & $2.8 \pm 2.9$ & $563.5 \pm 12.4$ \\
\hline & $\mathrm{N} 235$ & pt 506 & $7.7 \pm 2.6$ & $17.2 \pm 3.0$ & $475.0 \pm 32.9$ \\
\hline & N94 & pt 506 & $1.5 \pm 0.4$ & $3.2 \pm 0.1$ & $425.3 \pm 32.2$ \\
\hline & \multicolumn{2}{|c|}{ Mean for the group of pt 506} & $6.88 \pm 4.6$ & $6.09 \pm 6.9$ & $466.7 \pm 71.9$ \\
\hline & V15 & pt 90 & $1.8 \pm 0.1$ & $2.2 \pm 1.3$ & $312.0 \pm 68.2$ \\
\hline & V22 & pt 90 & $2.8 \pm 0.3$ & $23 \pm 9.7$ & $531.9 \pm 40.1$ \\
\hline & V291 & pt 90 & $4.6 \pm 1.2$ & $17 \pm 12$ & $406.1 \pm 22.5$ \\
\hline & V226 & pt 90 & $1.8 \pm 0.1$ & $4.3 \pm 2.6$ & $506.4 \pm 152$ \\
\hline & Mean for & of pt 90 & $2.73 \pm 1.3$ & $11.64 \pm 11.3$ & $439.4 \pm 117$ \\
\hline & Salmonella & lis (control) & $2.8 \pm 1.5$ & $3.5 \pm 1.5$ & $400 \pm 120$ \\
\hline
\end{tabular}

Unstimulated Caco-2 and IPI-2 cells released $12.9 \pm 0.14$ and $54.8 \pm 0.07 \mathrm{pg} / \mathrm{ml}$ IL-8, respectively.

${ }^{\mathrm{a}}$ Mean \pm SD of the number of bacteria attached per cell from triplicate wells.

${ }^{b}$ Mean \pm SD of the number of bacteria that invaded 100 cells from triplicate wells.

${ }^{\mathrm{c}}$ Mean \pm SD of IL-8 (pg/ml) secretion by the eukaryote cells after $1 \mathrm{~h}$ exposure to Salmonella Typhimurium isolates, measured from triplicate wells.

least $1 \mathrm{~h}$ in this medium prior to addition of the bacterial suspension. After incubating the cells and the bacteria for $1 \mathrm{~h}$ [20], the bacterial suspension was removed to exclude the unattached bacteria. The monolayers of epithelial cells were washed 3 times with DMEM, and $1 \mathrm{ml}$ Triton X-100 in PBS was added for $5 \mathrm{~min}$ at room temperature to release the bacteria from the cells. The number of adherent bacteria was estimated by plating serial dilutions. All experiments were performed in triplicate.

\subsection{Invasion assay}

After an incubation of $1 \mathrm{~h}$ as described in the adhesion assay, the bacterial suspension was removed. Cells were washed once with DMEM. One millilitre of DMEM containing colistin $(300 \mu \mathrm{g} / \mathrm{ml})$ was added and incubated for $2 \mathrm{~h}\left(37^{\circ} \mathrm{C}, 5 \%\right.$ $\mathrm{CO}_{2}$ ) to kill all extracellular bacteria. Next, the cell culture supernatant was collected 
and stored at $-20{ }^{\circ} \mathrm{C}$ for IL- 8 determination. The cells were washed 3 times with DMEM and lysed in 1\% Triton X-100 in PBS. The number of intracellular bacteria was determined by plate counting. All tests were performed in triplicate.

\subsection{IL-8 determination by sandwich ELISA}

IL-8 concentrations were determined using the human IL-8 Cytosets ${ }^{\mathrm{TM}}$ antibody pair kit containing matched, pretitred and fully optimized capture and detection antibodies, recombinant standards and streptavidin-horseradish peroxidase (Biosource Europe S.A., Belgium). The assay was performed according to the manufacturer's specifications. Porcine and human IL-8 have $80 \%$ homology (GenBank accession no. BAC06611 and NP000575, respectively) which explains the cross reactivity of human ELISA with porcine IL-8. Therefore, the equivalence unit to human IL-8 was indicated for porcine IL-8.

\subsection{Statistical analysis}

As all experiments were performed in triplicate, the mean values and the standard deviation were calculated and compared using the independent-samples $t$-test for groups of isolates or one-way ANOVA for individual isolates. Differences were considered significant at $p<0.05$. SPSS 12.0.1 for Windows was used.

\section{Results}

The results of the adhesion and invasion experiments are shown in Table 1. Generally, no significant differences $(p>0.05)$ in adherence and invasion to Caco-2 cells and IPI-2 cells by the two phage types of Salmonella Typhimurium was observed. Large differences were, however, observed between individual isolates $(p<0.05)$ of the same phage type (e.g. invasion of Caco- 2 cells by V15 compared to V22) and this result was reproducible, since the experiments were performed in triplicate and the results of the repeated testing for a certain strain were similar as can be seen from the standard deviations.

Exposure of the Caco-2 cells or IPI-2 cells to 200-500 bacteria/cell for $1 \mathrm{~h}$ induced IL-8 production significantly higher than that in the unstimulated cells (Table 1) $(p<0.05)$. No significant difference was observed between the IL-8 levels released by Caco-2 cells or IPI-2 cells $(p>0.05)$ upon stimulation of Salmonella Typhimurium phage type 506 compared to that of Salmonella Typhimurium pt 90 isolates.

\section{Discussion}

Salmonella Typhimurium DT 104 initially emerged in cattle in England and Wales. Subsequently, the strain has been isolated from many animal species including poultry, sheep, pigs and horses and has spread to other European countries 
and the USA. Salmonella Typhimurium DT 104 has caused human Salmonella outbreaks worldwide. In the present study the Salmonella Typhimurium pt 506 (DT 104) and Salmonella Typhimurium pt 90 isolates used exhibited the same level of adhesion to and invasion of Caco- 2 cells and IPI- 2 cells. This suggests that the ability of these two phage types to cause gastroenteritis is similar since the capacity to invade epithelial cells enables Salmonella to colonize and cross the epithelial barriers and starts the process of inflammatory diarrhea [14].

Initial adherence helps to bring Salmonella in close contact with the host cells. Better adhesion generally means a higher chance of invasion but a bacterial strain with a high capacity to adhere will not always invade eukaryotic cells to a higher extent. For instance isolate V15 attached to Caco-2 cells better than isolate V22 (21.6 and 2 bacteria/cell, respectively) but a lower number of isolate V15 invaded Caco-2 cells compared to isolate V22 (3.5 and 11.2 bacteria/100 cells, respectively).

The next step in the interaction between Salmonellae and host cells involves the secretion of virulence factors by type III secretion systems (TTSS) [21]. The TTS apparatus present in all Salmonella enterica strains, resembles a needle-like structure and injects Salmonella flagellin protein into eukaryotic cells. The interaction between flagellin proteins and TLR-5 lead to IL- 8 production by the eukaryotic cells [11]. It is known that Caco-2 cells express TLR-5 [22]. Recently, a porcine jejunal epithelial cell line (IPEC-J2) has been defined to express TLR-5 [23]. IL-8 production by Caco2 cells was found after exposure to purified Salmonella flagellin but not detected in the absence of purified flagellin [22]. Induction of an IL-8 release by epithelial cells is dependent on the invasive capacity of the Salmonella strain [13,24,25]. In the present study, a better invasion of Salmonellae leading to a higher IL-8 production by human and porcine cell lines was observed in almost all Salmonella isolates except the isolate N176 to IPI-2 cell.

IL-8 promotes neutrophil transmigration [26] into the intestinal lumen, leading to enterocyte injury. Data of the present study show that high IL-8 levels were released by Caco-2 or IPI-2 cells upon stimulation of the Salmonella Typhimurium isolates regardless differences in the two phage types. Therefore, in addition to comparative levels of invasion to the cell lines of Salmonella Typhimurium pt 506 and Salmonella Typhimurium pt 90, the isolates of these two phage types also stimulated the cell lines to produce a high amount of IL-8. One may speculate that a strong inflammatory reaction may occur in the host. Infections caused by Salmonella Typhimurium pt 506 (or DT 104) are well documented [27]. The present study suggests that Salmonella Typhimurium pt 90 has a similar ability to cause Salmonella infections.

In conclusion, Salmonella Typhimurium phage type 506 and Salmonella Typhimurium phage type 90 adhered to and invaded human and porcine epithelial cells equally well. Both phage types induced a similar IL-8 response. Therefore, the differences in the surface structure of the two phage types of Salmonella Typhimurium do not influence in vitro pathogenicity of Salmonella Typhimurium phage type 506 and Salmonella Typhimurium phage type 90 regarding adhesion, invasion of Caco-2 and IPI-2 cell lines and the stimulation of these cell lines to produce IL-8. 


\section{Acknowledgment}

This study was supported by a grant from the Vietnamese Government in the Project 322 for An Vo.

\section{References}

[1] WHO Global Salm-Surv. Top 15 Salmonella serotype list from each country. 23 March $2005<$ http:// thor.dfvf.dk/pls/portal/GSS.COUNTRY_DATA_SET_REP.show $>$.

[2] van Duijkeren E, Wannet WJ, Houwers DJ, van Pelt W. Serotype and phage type distribution of Salmonella strains isolated from humans, cattle, pigs, and chickens in The Netherlands from 1984 to 2001. J Clin Microbiol 2002;40:3980-5.

[3] Baggesen DL, Sandvang D, Aarestrup FM. Characterization of Salmonella enterica serovar Typhimurium DT104 isolated from Denmark and comparison with isolates from Europe and the United States. J Clin Microbiol 2000;38:1581-6.

[4] Ang-Kucuker M, Tolun V, Helmuth R, Rabsch W, Buyukbaba-Boral O, Torumkuney-Akbulut D, et al. Phage types, antibiotic susceptibilities and plasmid profiles of Salmonella Typhimurium and Salmonella Enteritidis strains isolated in Istanbul, Turkey. Clin Microbiol Infect 2000;6:593-9.

[5] Yang SJ, Park KY, Kim SH, No KM, Besser TE, Yoo HS, et al. Antimicrobial resistance in Salmonella enterica serovars Enteritidis and Typhimurium isolated from animals in Korea: comparison of phenotypic and genotypic resistance characterization. Vet Microbiol 2002;86:295-301.

[6] Vo AT, van Duijkeren E, Fluit AC, Heck ME, Verbruggen A, Maas HM, et al. Distribution of Salmonella enterica serovars from humans, livestock and meat in Vietnam and the dominance of Salmonella Typhimurium phage type 90. Vet Microbiol 2006;113:153-8.

[7] Heller KJ. Molecular interaction between bacteriophage and the gram-negative cell envelope. Arch Microbiol 1992;158:235-48.

[8] Salgado CJ, Zayas M, Villafane R. Homology between two different Salmonella phages: Salmonella enterica serovar Typhimurium phage P22 and Salmonella enterica serovar Anatum var. 15+ phageepsilon34. Virus Genes 2004;29:87-98.

[9] Anderson ES, Ward LR, Saxe MJ, de Sa JD. Bacteriophage-typing designations of Salmonela typhimurium. J Hyg (Lond) 1977;78:297-300.

[10] Guinee PA, van Leeuwen WJ, Pruys D. Phage typing of $S$. Typhimurium in The Netherlands. 1. The phage typing system. Zentralbl Bakteriol 1974;226:194-200.

[11] Hayashi F, Smith KD, Ozinsky A, Hawn TR, Yi EC, Goodlett DR, et al. The innate immune response to bacterial flagellin is mediated by Toll-like receptor 5. Nature 2001;410:1099-103.

[12] Harada A, Sekido N, Akahoshi T, Wada T, Mukaida N, Matsushima K. Essential involvement of interleukin-8 (IL-8) in acute inflammation. J Leukoc Biol 1994;56:559-64.

[13] Scherer CA, Miller SI. Molecular pathogenesis of Salmonellae. In: Groisman EA, editor. Principles of bacterial pathogenesis. New York: Academic press; 2001. p. 247-333.

[14] Jones GW, Richardson LA, van den Bosch JL. Phases in the interaction between bacteria and animal cells. In: Berkeley RCW, Luynch JM, Melling J, Rutter PR, Vincent B, editors. Microbial adhesion to surfaces. London: Ellis Horwood limited; 1980. p. 211-9.

[15] Vo AT, van Duijkeren E, Fluit AC, Gaastra W. Antibiotic resistance, integrons and Genomic Island SGI1 among non-typhoid Salmonella serovars in The Netherlands. Int J Antimicrob Agents 2006;28:172-9.

[16] van Asten FJ, Hendriks HG, Koninkx JF, Van der Zeijst BA, Gaastra W. Inactivation of the flagellin gene of Salmonella enterica serotype Enteritidis strongly reduces invasion into differentiated Caco-2 cells. FEMS Microbiol Lett 2000;185:175-9.

[17] Kusters JG, Mulders-Kremers GA, van Doornik CE, van der Zeijst BA. Effects of multiplicity of infection, bacterial protein synthesis, and growth phase on adhesion to and invasion of human cell lines by Salmonella Typhimurium. Infect Immun 1993;61:5013-20. 
[18] Hendriks H, van Asten A, Koninkx J, Kok W, van der Zeijst B, van Dijk J. Interactions between Salmonella Enteritidis and the enterocyte-like human carcinoma cell line Caco-2. In: Bardocz S, Nekrep FV, Pusztai A, editors. Effects of antinutrients on the nutritional value of legume diets. Luxemburg: Office Official Publications European Communities; 1996. p. 137-9.

[19] Kaeffer B, Bottreau E, Velge P, Pardon P. Epithelioid and fibroblastic cell lines derived from the ileum of an adult histocompatible miniature boar (d/d haplotype) and immortalized by SV40 plasmid. Eur J Cell Biol 1993;62:152-62.

[20] Hendriks H, van Asten A, Koninkx J, van der Zeijst B, van Dijk J. Interactions between Salmonella enteritidis and the enterocyte-like human colon carcinoma cell line Caco-2. In: Bardocz S, Nekrep F, Pusztai A, editors. Effects of antinutrients on the nutritional value of legume diets. Luxembourg: Cost 98, Office for Official Publications of the European Communities; 1996.

[21] Ehrbar K, Hardt WD. Bacteriophage-encoded type III effectors in Salmonella enterica subspecies 1 serovar Typhimurium. Infect Genet Evol 2005;5:1-9.

[22] van Asten F. The moving story on the flagella of Salmonella serotype Enteritidis (PhD thesis), Utrecht, The Netherlands, 2005.

[23] Burkey TE. Expression of Toll-like receptors in porcine immune cells and tissues, 16 July $2006<$ http://hdl.handle.net/2097/153>.

[24] Hobbie S, Chen LM, Davis RJ, Galan JE. Involvement of mitogen-activated protein kinase pathways in the nuclear responses and cytokine production induced by Salmonella Typhimurium in cultured intestinal epithelial cells. J Immunol 1997;159:5550-9.

[25] Schierack P, Nordhoff M, Pollmann M, Weyrauch KD, Amasheh S, Lodemann U, et al. Characterization of a porcine intestinal epithelial cell line for in vitro studies of microbial pathogenesis in swine. Histochem Cell Biol 2006;125:293-305.

[26] McCormick BA, Colgan SP, Delp-Archer C, Miller SI, Madara JL. Salmonella Typhimurium attachment to human intestinal epithelial monolayers: transcellular signalling to subepithelial neutrophils. J Cell Biol 1993;123:895-907.

[27] Helms M, Ethelberg S, Molbak K. International Salmonella Typhimurium DT104 infections, 1992-2001. Emerg Infect Dis 2005;11:859-67. 